\title{
心臓突然死予防に関する最新知見
}

\section{Overview of Recent Findings on Prevention of Sudden Cardiac Death}

\begin{abstract}
《Abstract》
年間 7 万人を超える心臓突然死のほとんどは心室細動によって起こるが，その予防が困難である現 在, 頼れる救命法は除細動器の活用である. ハイリスクであることが固定していれば植込み型除細動器 (ICD)，その評価が未定な時期には着用型自動除細動器 (WCD) が利用できるが, 正確なリスク評価は決 して容易でない，さらに，突然死最大の原因である急性冠症候群の例をはじめ，多くの症例は直前まで 受診していないか, リスクを予知されていないため, 現場で迅速な除細動を施すしか救命を保証する術 はない。 今や, 目撃された心原性心停止に対して現場の市民が自動体外式除細動器(AED)を使えば, $50 \%$ が救命可能な時代に入つたが，今後も不特定多数への AED 対応体制を充実させつつ，特定グルー プ，さらには個人への集中救命対応の推進が求められ，その成果が期待される.
\end{abstract}

\section{I .はじめに}

日本では，年間 7 万人を超える人が心臓突然死で 亡くなっている。心臓突然死の多くは心室細動 (VF)によると考えられるものの，その頻度の解明 はほとんど不可能である。院外においては心停止発 症直後の心電図は得られず，救急隊到着時の心電図 波形で判断するしかないが, 多くの場合, それは心 停止後 10 分以上経過した時点の記録であり，当初 VFであった波形も，この頃にはフラットになって 心静止と判定されることが多くなる。今後, 現場に おけるより早期の心電図記録の解析が進めば，初期 調律がVFである例の比率は，さらに実態に近づく ものと期待される.

本来ならば，このVFが発生する前にそれを予知
できれば，予防も可能となるが，後述するようにそ の予知は容易でないため, むしろ VF発生後により 確実な治療法である除細動をいかに施すかが，当 面，最も有効な手段として重視されている．本稿で は，主にその除細動の有用性と，そのためのアプ ローチについて，最新知見を交えて紹介したい。

\section{II. ハイリスク例に対するICD，WCDによる 心臓突然死の予防}

院外心停止の初期調律がVFの場合には，迅速な 除細動によってのみ，心停止からの蘇生がもたらさ れるが，蘇生率は電気ショックが1分遅れるごとに 7 ～10\%ずつ，時間依存性に低下する ${ }^{1)}$. 院外にお いて, VF発生後に最も早く電気ショックを与える には植达み型除細動器 (ICD)による方法が最適であ

国家公務員共済組合連合会立川病院（ $\bar{T}$ 190-8531 東京都立川市錦町 4 丁目 2-22）

Hideo Mitamura

- Key words ; 心臟突然死, 心室細動, 植込み型除細動器 (ICD), 着用型自動除細動器 (WCD), 自動体外式除細動器 (AED) 
り, 次いで着用型自動除細動器 (WCD) を用いる方 法があるが，いずれも突然死のリスクを有する特定 の個人が対象となる．前者は心停止の原因が徐脈性 であっても有効であるが，手術という侵襲を伴うた め長期的な予防目的で行われるのに対し，後者は非 侵襲的である反面, 毎日着衣する煩雑性や着衣のま ま入浴はできないなど日常生活に支障をきたすた め, 長期使用には適さず, 通常 3 カ月までの利用 にとどまる。

$\mathrm{VF}$ の既往があり, 蘇生された例では二次予防と しての ICDが植込まれ, その効果はアミオダロン を中心とするいかなる薬物療法の効果よりも高く ${ }^{2)}$, VFが一過性可逆性の原因による場合を除き，その 適応に疑問の余地はない。しかし，いまだ致死的不 整脈の出現を見ていない例に対する一次予防目的と なると，その侵襲性や医療費に見合うリスクといえ るか否かの評価が必要となる。これまでいろいろな 臨床因子がそのリスク評価のために利用されてきた が, 最も高いエビデンスが得られているのが急性心 筋梗塞 (AMI) 後の左室駆出率 (LVEF) である ${ }^{3), 4)}$. LVEFが低いほど，突然死のリスクが高くなること は間違いないが，この LVEFは AMI後に変化する ため ${ }^{5)}$, どの時点の LVEFをもとに ICDの適応を 決めるべきかという問題がある。また，大規模臨床 試験において, AMI直後の低 LVEF例への ICDに よる突然死，心不全死などを合わせた生命予後の改 善が示されていないことも，植込み指針を複雑にし ている ${ }^{6)}$.7).

2012 年 $\mathrm{ACCF} / \mathrm{AHA} / \mathrm{HRS}$ ガイドライン ${ }^{8)}$ では, $\mathrm{AMI}$ 後の ICDのクラス I適応として, 以下の基準 を提唱している.

(1) $\mathrm{LVEF} \leqq 40 \%+$ inducible $\mathrm{VF} /$ sustained VT

(2) $\mathrm{LVEF} \leqq 35 \%+$ NYHA II / III @ $\geqq 40$ days post-MI

(3) LVEF $\leqq 30 \%+$ NYHA I @ $\geqq 40$ days post-MI

これによると, AMI後 40 日間には LVEFが低く ても ICDが推奨されないことになるが，この時期 の突然死リスクは実際には高い ${ }^{3)}$ 。そこで, 不整脈 死を回避するためにWCDがあり，最終的に ICD の
要否を決めるまでの経過処置 (ブリッジ)として用い られている ${ }^{9)}$.

一方，実臨床においては，これらの基準を満たし た例であっても，高齢者・認知症例・透析例などで はICDによる一次予防処置がとられないケースも 少なくない，米国オレゴン州の報告によれば, 院外 心停止 2,093例のうち, 21\%で LVEFデータが存在 したが，そのうち LVEFが 35\% 以下の例は $32 \%$ で, 実際に一次予防としての ICDが植込まれていたの は $13 \%$ にすぎなかったという (図 1) ${ }^{10)}$.

さらに問題となるのは, 実臨床においては LVEF が保たれた例の突然死のほうが，むしろ多いことで ある．海外のデー夕によると，院外突然死例のおよ そ $45 \%$ は受診歴のない一見健康な患者であり，40\% は器質的心疾患を有するものの LVEF > 40\%であ り，LVEF＜ 40\%は 13\%の例にすぎず，あとは遺 伝子異常による不整脈病とされる $\left(\right.$ 図 2) ${ }^{11)}$. LVEF が保たれたハイリスク例の選別には, 従来から左室 径· QRS 幅・遅延電位・非持続性 VT ・ 心拍変動 QT dispersion・T波変動などが利用されてきたが, いずれの指標も特異度が十分高いとはいえない. 最 近では, 特に心筋梗塞例における周期性再分極変動 の有用性が注目されている ${ }^{12)}$.

\section{III. 心臓突然死の誘因と予知の限界}

器質的心疾患例における突然死のリスク評価法が 進歩し, ハイリスク症例への除細動器植込み, ある いは装着が効果を上げつつあることは間違いない が，院外突然死の大多数はむしろ，そのようなリス ク評価法では選別されず，一見すると，健常者であ るという事実を冷静に受け止めなければならない ${ }^{13)}$.

国内で心臓突然死をきたした患者背景について は, 千葉北総病院に搬送された心血管性の院外心 停止から蘇生された 15 歳以上の 121 例の分析があ る ${ }^{14)}$. それによると, 急性冠症候群が約半数の $53 \%$ 占めており，次いで心筋症が $22 \%$ 占めて いた(図 3). 日本では冠攣縮も重要な心停止原因で あり，7\%を占めるため，虚血全体としては約 $60 \%$ 


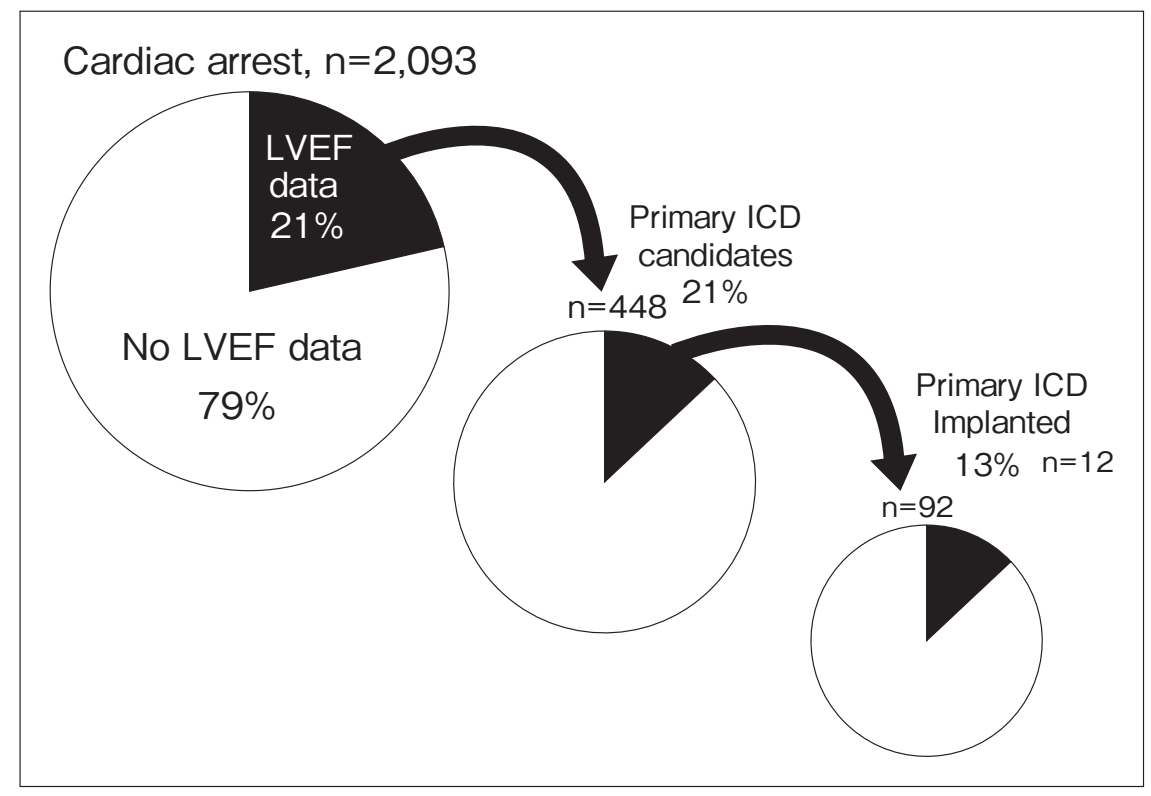

図 1

心停止例におけるICD 一次予防適 合患者の割合と実施率

〔文献 10)より引用改変〕

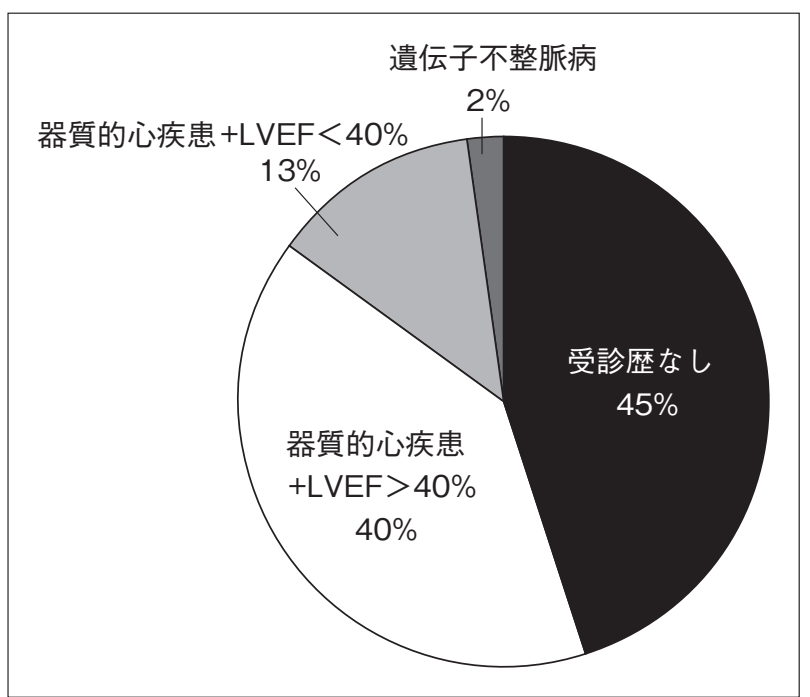

図 2 心臟突然死患者の背景

〔文献 11)より引用改変〕

を占めることになる.

その意味では，虚血性心疾患をより早期に検出す ることが重要となるが，すべての例が事前に狭心症 を呈するとは限らない。 心原性心停止直前の症状に ついて調べた報告によると，27\%に息苦しさ，21\% に胸痛，13\%に失神を直前に認めたにすぎない (図 4) ${ }^{15)}$. 梗塞前狭心症は, むしろ VFの発生を半

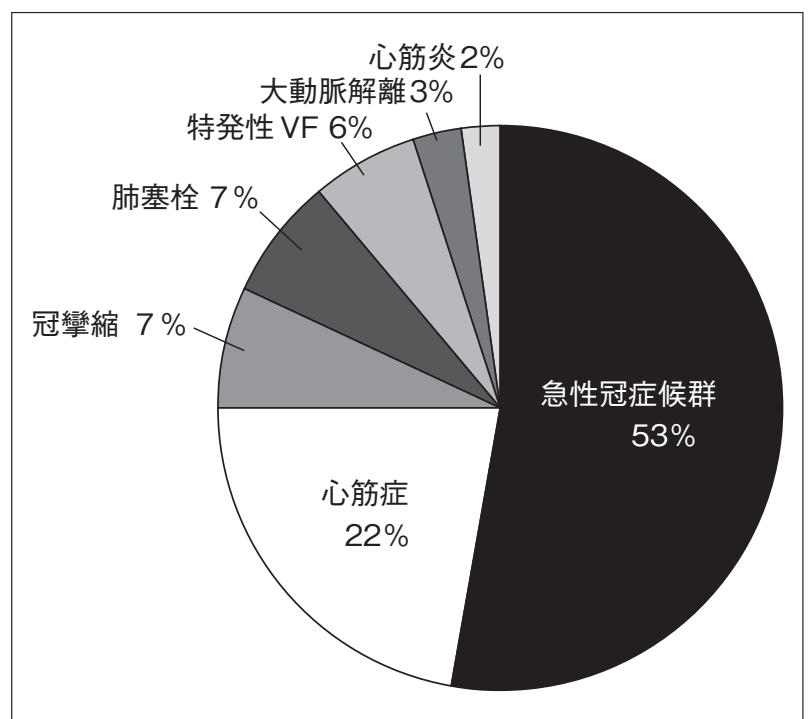

図 3 心停止蘇生例の基礎心疾患

〔文献 14）より引用改変〕

減させるとの報告もあり ${ }^{16)}$ ，前兆に頼るだけでは 突然死の防止に十分とはいえない.

VFの発生は AMIによる入院後とは限らず，初 発症状が突然死という例も少なくない. 長野県松本 市で 1 年間にわたり，急性冠閉塞例の実態について, 病院のみならず監察医務院も含めて調べた研究によ ると, $27 \%$ が病院到着前に心停止をきたしていた 


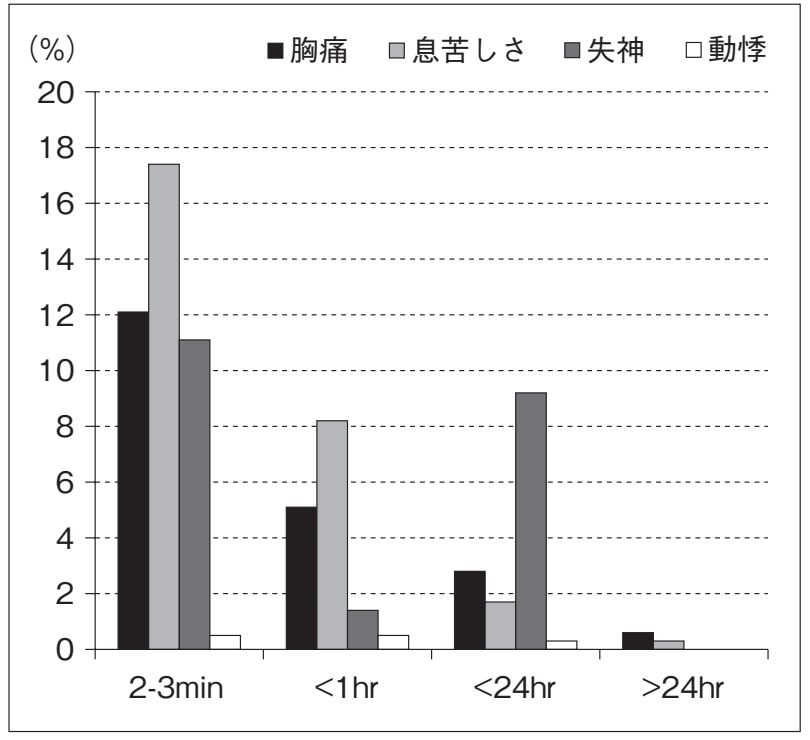

図4 院外心停止の前兆

〔文献 15)より引用改変〕

表 AMI超急性期 (入院前/救急外来) におけるVF 発生の危険因子

\begin{tabular}{|c|c|c|}
\hline 因子 & 多変量オッズ比 & $\mathrm{p}$ \\
\hline 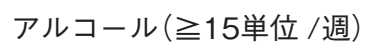 & 3.30 & $<0.001$ \\
\hline 心房細動 & 2.80 & 0.040 \\
\hline STEMI発症前のスタチン & 2.10 & 0.020 \\
\hline 梗塞部位 (前壁) & 2.10 & $<0.001$ \\
\hline 若年 (<60 歳) & 1.75 & 0.005 \\
\hline TIMI flow grade 0 (閉塞) & 1.65 & 0.008 \\
\hline 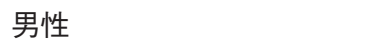 & 1.65 & 0.060 \\
\hline 突然死の家族歴 & 1.60 & 0.010 \\
\hline 梗塞前狭心症 & 0.46 & $<0.001$ \\
\hline 高脂血症 & NS & \\
\hline 高血圧 & NS & \\
\hline 喫煙 & NS & \\
\hline
\end{tabular}

STEMI : ST-segment elevation myocardial infarction, TIMI : thromboysis in myocardial infarction

〔文献16）より引用改変]

という ${ }^{17)}$. また海外の研究で, ST上昇型 AMIの 超急性期 (83\% は病院到着前, 17\% は救急外来)に VFを呈した 219 例を分析した結果では，週に15単 位以上の飲酒歴が，VFのオッズ比を 3.3 倍高める ことがわかっており, 前壁梗塞や心房細動合併と いった要素以上に重要な交絡因子として注目されて

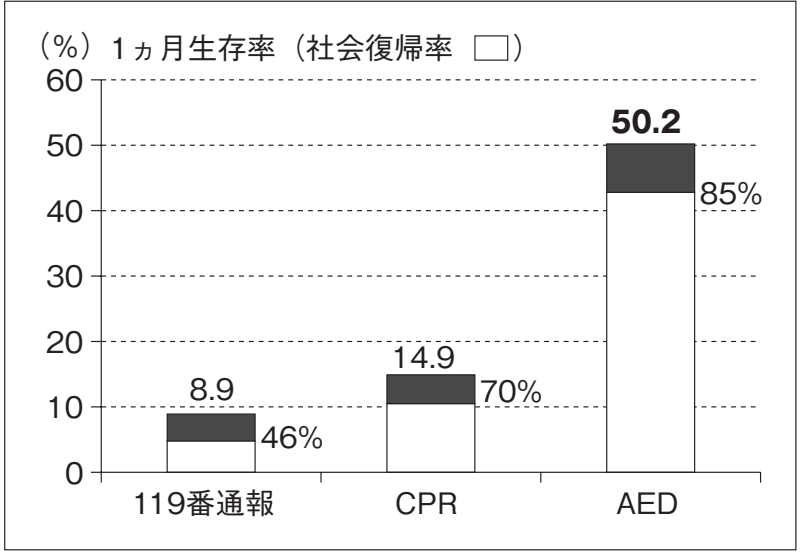

図 5 目撃された心原性心停止の救命率と社会復帰率 CPR : cardiopulmonary resuscitation

〔文献 22)より引用改変]

いる(表) ${ }^{16)}$.

突然死の発生パターンは，その主要原因である $\mathrm{AMI}$ の発生パターンに類似し，いくつかの特徴が ある。例えば，季節でいえば 12 月から 2 月までの 冬で，曜日としては月曜，時刻は 10 時から 12 時ま での午前中に多く発症するという特徵が指摘されて いる ${ }^{18)}$. 75歳以上の高齢者における突然死のリス クは気温にも関係しており，特に $18^{\circ} \mathrm{C}$ を回ると, $5{ }^{\circ} \mathrm{C}$ 低下するごとに $16 \%$ ずつ増加するといわれる ${ }^{19)}$. ストレスも重要な誘因とされ, 大震災直後に突然死 が増加したことが報告されている ${ }^{20)}$.

虚血性心疾患は，循環器内科医が日常診療してい る代表的な疾患であり，その治療は劇的に進歩して いるが，恩恵にあずかれない突然死患者の多いこと も忘れてはならない. 予知予防には限界があり, 救 命をより確かなものにするには, VF 発生後の処置, すなわち迅速な除細動の有無が鍵となる.

\section{IV.AEDを活用した public access defibrillation とその成果}

非常時に迅速に除細動を行うには，患者を病院に 運んでからではなく，倒れたその場で除細動を行う ことが必須であり，それには平均 8.5 分かかるとい われる救急車の到着を待つ余裕はない. 現場での除 
細動(public access defibrillation)が可能になったの は，素人でも使える自動体外式除細動器 (AED)の 登場によるものであるが，日本でその使用が一般人 に許可されたのは 2004 年 7 月のことである ${ }^{21)}$ 。以 来，50万台を超える AEDが世の中に出回ることと なった，総務省消防庁の発表によると，2013年の 1 年間に目撃された心原性心肺停止例は 25,469 件で あったが，そのうち市民が AEDを使用したのが 907 件で, 現場での除細動の結果, 1 カ月後に生存 できたのは 455 件，社会復帰できたのが 388 件で あった ${ }^{22)}$ 。このように，目撃された心原性心停止 例に対して，現場の市民が AEDを用いた除細動を 行えば $50.2 \%$ の命が救われ，そのうち $85 \%$ が社会 復帰できることが証明された(図 5)。それに対し て，119番通報だけで，救急車の到着を待つのみで は $8.9 \%$ の生存率しか得られず，社会復帰はその $46 \%$ にすぎなかった。ちなみに，現場の市民が何ら かの心肺蘇生術を行った場合には，14.8\%の生存率 が得られ，そのうち $70 \%$ が社会復帰している。

しかし，現場で実際に AEDが使われるか否かは， AEDの分布 (public access)によるところも大きい. 2005 年から 2007 年にわたる日本全国の統計解析に よれば，心停止からの救命率は AEDの設置台数と 密接に関係しており，居住地域 1 平方キロ当たり 1 台未満の設置地域と比べて，4台以上設置されてい る地域では，倒れてから除細動までの時間が 3.7 分 から 2.2 分に短縮し，重篤な神経学的後遺症なしに 社会復帰できる確率が，昼間人口 1 千万人当たり年 間 2.4 件から 8.9 件に改善することが示されている ${ }^{23)}$. このように，AEDの分布密度が高まれば，救命率 も増加することは間違いない。

AEDの公的インフラとしては，すでに東京都や 神奈川県では全交番に AEDが配備されたほか，鳥 取県, 神奈川県では一部パトカーにも AEDが搭載 されている。これら先進的な取り組みは，住民の安 心を確保する上で高く評価されるものであり，早急 に全国に広まることが望まれる。ほかにも，住民生 活の拠点であり, かつ 24 時間アクセス可能なコン
ビニエンスストアへの AED設置も歓迎されてい る. すでに千葉県船橋市, 沖縄県那覇市, 兵庫県宝 塚市，神奈川県大和市，静岡県三島市，埼玉県三郷 市，茨城県龍ヶ崎市，大阪府枚方市などの自治体が コンビニへの $\mathrm{AED}$ 設置を推進しており，それによ る救命例も報告されている。しかし，これを全国的 に展開させるには各自治体任せではなく，国家行政 が率先して取り組む姿勢が求められる.

不特定多数を相手にする救命体制の構築には AEDの設置充足のみならず，使用者側の市民への 協力要請にも改善の余地がある．啓発や教育といっ たアプローチのほかに，Social Networkを活用しよ うという試みが進行している。具体的には，第一発 見者がスマートフォンでSOSを発信すると，それ が，例えば半径 $500 \mathrm{~m}$ 以内にいる他の加入者にプッ シュ通信され，それを受けた人が応援に向かう，近 辺の AEDを取って駆けつける，という仕組みであ る.このような相互扶助の現代版とも呼べるアイ

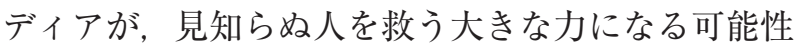
がある。

\section{Targeted defibrillation と home AED の可能性}

突然死はいつ, どこで, 誰に起こるかわからない． 数分以内の除細動のために，全国すべての場所に AED を配備することは, 費用対効果を考えると決 して効率的とはいえない.むしろ限定された場所 に，限定された時間に，限られた資源を投入すれ ば，かなりの効果が期待できる。このように特定 の集団を救命のターゲットとするのが, targeted defibrillationである.

特に, 駅や電車内, 空港や航空機内などは人口密 度が高いため心停止の瞬間が目撃されやすく, 機敏 に動ける若者が多いことから, チームワークが機能 しやすい. 同様に, スポーツジムやプールなどの運 動施設も発作が目撃されやすい上に, 職員や指導員 らに救命の心得のある者が多い。したがって，これ らの場所に重点的に AEDを配置することは，より 効率的といえる。2006 年 1 月から 2008年 5 月まで 
に, 都内で AEDによる電気ショックが施された 145 件の分析によると, $32 \%$ が駅, $13 \%$ がスポーツ 施設, $11 \%$ が職場の AEDを使用していた ${ }^{24)}$. 実際 に救命に成功した事例は，(1)目撃され，(2)心肺蘇生 術を受け，(3) AEDが使用される，という3 条件を 満たした例に多い.

2005 年の愛知万博では, $300 \mathrm{~m}$ 間隔で合計 100 台 の AEDが配置されたが，この間隔は最大 $150 \mathrm{~m}$ の 距離を 1 分で走れば，合計 2 分でAEDを現場に運 ベることを意味していた，会期中に 5 名の心停止が あり，そのうち 4 名 $(80 \%)$ が AEDによって救命さ れた。この1分で取りに行ける距離に AEDを配置 する, という目安は, 今後も様々な場面で役に立つ と思われる. しかし， $42.195 \mathrm{~km}$ を走るマラソンと なると, AED 配備は簡単ではない. そこで, 東京 マラソンでは合計 75 台の AEDをコースの所々に配 置したのみならず，自転車モバイル隊 22 名が AED を背負ってランナーらの横を併走したのである. そ の結果，これまで 9 回の大会で，7人のランナーが レース中に心停止に陥ったが，その 7 人全例 (100\%) がAEDによって救命された.

Targeted defibrillationが突然死をゼロに近づけ られる，という事実は極めて重要で，次の夕ーゲッ トとして位置づけられるのが学校である. 小中学校 における心原性心停止の半数近くは心疾患の管理例 であるが，未診断の子供が運動中に心停止をきたし たり，何の病気もなくてもボールが胸に当たって心 臓震盪を起こしたりする．特に，小中学校における 心原性心停止は $97 \%$ が目撃され，84\%が運動に関 連して起こっているため, 運動現場の近くに AED を配置することは極めて効果的といえる ${ }^{25)}$. 今や ほとんどの学校に AEDが設置されているが, AED が学校に徐々に導入された 2005年から 2009年まで に, 小中学生の心室細動による心停止に対して目撃 者が除細動を試みた頻度は年間 2\%から $21 \%$ に増加 し, その結果, 社会復帰率も $12 \%$ から $36 \%$ に改善 した ${ }^{26)}$. なかでも, 小中学校内の心停止に限れば, 69\%の社会復帰率を示したとする報告もある ${ }^{25)}$. そ
のような背景から, 学校における突然死ゼロを目指 す提言が日本循環器学会 AED 検討委員会から公開 され ${ }^{27)}$, 学校内のどの場所に AEDを置き, 誰がど のように手分けして心停止に対処したらよいか，と いった具体的な対策を提示するとともに，日頃から の準備対策・生徒児童への教育など, 幅広い提案が 示されている.

究極の targeted defibrillationは，自宅にAEDを 配備するものである. 心蔵突然死の 4 分の 3 は自宅 で起こるため, 心臓病患者の自宅に AEDを用意し ておくことは理にかなっている.しかし，この home AEDの有用性を検討した研究では, これま でのところ，否定的な報告しか得られていない，前 壁心筋梗塞後の患者を対象に，前向きに検討した HAT (Home Automated External Defibrillator Trial) とよばれる大規模試験結果では ${ }^{28)}$, 心筋梗塞 後で ICD 植达みの適応のない例を 2 群に分け, $\mathrm{AED}$ 群では家人が AED を使ってから救急センター に電話連絡, コントロール群ではセンターに電話し てから心肺蘇生術を実施する，というプロトコール を採用した. 37.3 カの追跡の結果, 両群の間に全 死亡率の差は認められなかった。この試験から, 心 筋梗塞後の患者の家に AED を用意していても, (1) 心停止の頻度が低く, (2)心停止であっても, それが 心破裂など不整脈以外の原因で生じることがあり， (3)致死性不整脈によるものでも, その発生時に本人 が外出していたり，あるいは(4)在宅中であっても， 家人が外出中である，または(5)共に在宅していても (睡眠中，入浴中など)，家人に目撃されていないこ とが多く, さらに(6)条件がそろっていても, 家人(し ばしば高齢女性) が火急の際に AEDを使用できな いことが少なくないことが明らかとなった。

しかし, 将来的に AEDのコストの低下とともに, ハイリスク患者の選別が進み, 非目撃時の心停止を 瞬時に診断する, 例えば腕時計型検知器のテクノロ ジーと, それを家人に知らせるシステムが開発され れば, home AEDの有用性が再度注目を集めるも のと期待される. 


\section{〔文献〕}

1) Guidelines 2000 for Cardiopulmonary Resuscitation and Emergency Cardiovascular Care. The American Heart Association in collaboration with the International Liaison Committee on Resuscitation. Circulation, $2000 ; 102$ (Suppl) : I-22 I-76

2 ) The Antiarrhythmics versus Implantable Defibrillators (AVID) Investigators: A comparison of antiarrhythmic-drug therapy with implantable defibrillators in patients resuscitated from near-fatal ventricular arrhythmias. N Engl J Med, 1997 ; 337 : $1576 \sim 1583$

3 ) Solomon SD, Zelenkofske S, McMurray JJ, Finn PV, Velazquez E, Ertl G, Harsanyi A, Rouleau JL, Maggioni A, Kober L, White H, Van de Werf F, Pieper K, Califf RM, Pfeffer MA ; Valsartan in Acute Myocardial Infarction Trial (VALIANT) Investigators : Sudden death in patients with myocardial infarction and left ventricular dysfunction, heart failure, or both. N Engl J Med, $2005 ; 352: 2581 \sim 2588$

4) Moss AJ, Zareba W, Hall WJ, Klein H, Wilber DJ, Cannom DS, Daubert JP, Higgins SL, Brown MW, Andrews ML; Multicenter Automatic Defibrillator Implantation Trial II Investigators : Prophylactic implantation of a defibrillator in patients with myocardial infarction and reduced ejection fraction. $\mathrm{N}$ Engl J Med, $2002 ; 346: 877 \sim 883$

5 ) Sjöblom J, Muhrbeck J, Witt N, Alam M, FrykmanKull V : Evolution of left ventricular ejection fraction after acute myocardial infarction : implications for implantable cardioverter-defibrillator eligibility. Circulation, $2014 ; 130: 743 \sim 748$

6 ) Hohnloser SH, Kuck KH, Dorian P, Roberts RS, Hampton JR, Hatala R, Fain E, Gent M, Connolly SJ ; DINAMIT Investigators : Prophylactic use of an implantable cardioverter-defibrillator after acute myocardial infarction. N Engl J Med, 2004 ; 351 : $2481 \sim 2488$

7 ) Steinbeck G, Andresen D, Seidl K, Brachmann J, Hoffmann E, Wojciechowski D, Kornacewicz-Jach Z, Sredniawa B, Lupkovics G, Hofgärtner F, Lubinski A, Rosenqvist M, Habets A, Wegscheider K, Senges J ; IRIS Investigators : Defibrillator implantation early after myocardial infarction. N Engl J Med, 2009 ; 361 : $1427 \sim 1436$

$8)$ Tracy CM, Epstein AE, Darbar D, DiMarco JP, Dunbar SB, Estes NA 3rd, Ferguson TB Jr, Hammill SC, Karasik PE, Link MS, Marine JE, Schoenfeld MH, Shanker AJ, Silka MJ, Stevenson LW, Stevenson WG, Varosy PD, Ellenbogen KA, Freedman RA, Gettes LS,
Gillinov AM, Gregoratos G, Hayes DL, Page RL, Stevenson LW, Sweeney MO ; American College of Cardiology Foundation; American Heart Association Task Force on Practice Guidelines ; Heart Rhythm Society : 2012 ACCF/AHA/HRS focused update of the 2008 guidelines for device-based therapy of cardiac rhythm abnormalities : a report of the American College of Cardiology Foundation/American Heart Association Task Force on Practice Guidelines and the Heart Rhythm Society. Circulation, 2012 ; 126(14) : $1784 \sim 1800$

9) Epstein AE, Abraham WT, Bianco NR, Kern KB, Mirro M, Rao SV, Rhee EK, Solomon SD, Szymkiewicz SJ : Wearable cardioverter-defibrillator use in patients perceived to be at high risk early post-myocardial infarction. J Am Coll Cardiol, 2013 ; 62 : 2000 2007

10) Narayanan K, Reinier K, Uy-Evanado A, Teodorescu $C$, Chugh H, Marijon E, Gunson K, Jui J, Chugh SS ; the Oregon Sudden Unexpected Death Study : Frequency and determinants of implantable cardioverter defibrillator deployment among primary prevention candidates with subsequent sudden cardiac arrest in the community. Circulation, $2013 ; 128: 1733 \sim 1738$

11) Wellens HJ, Schwartz PJ, Lindemans FW, Buxton AE, Goldberger JJ, Hohnloser SH, Huikuri HV, Kääb S, La Rovere MT, Malik M, Myerburg RJ, Simoons ML, Swedberg K, Tijssen J, Voors AA, Wilde AA : Risk stratification for sudden cardiac death : current status and challenges for the future. Eur Heart J, $2014 ; 35$ : $1642 \sim 1651$

12) Rizas KD, Nieminen T, Barthel P, Zürn CS, Kähönen M, Viik J, Lehtimäki T, Nikus K, Eick C, Greiner TO, Wendel HP, Seizer P, Schreieck J, Gawaz M, Schmidt G, Bauer A : Sympathetic activity-associated periodic repolarization dynamics predict mortality following myocardial infarction. J Clin Invest, $2014 ; 124$ : $1770 \sim 1780$

13) Myerburg RJ, Spooner PM : Opportunities for sudden death prevention : directions for new clinical and basic research. Cardiovasc Res, $2001 ; 50: 177 \sim 185$

14) Kobayashi N, Hata N, Shimura T, Yokoyama S, Shirakabe A, Shinada T, Tomita K, Murakami D, Takano M, Seino Y, Matsumoto H, Mashiko K, Mizuno $\mathrm{K}$ : Characteristics of patients with cardiac arrest caused by coronary vasospasm. Circ J, $2013 ; 77$ : $673 \sim 678$

15) Nishiyama $C$, Iwami $T$, Kawamura $T$, Kitamura $T$, Tanigawa K, Sakai T, Hayashida S, Nishiuchi T, Hayashi Y, Hiraide A : Prodromal symptoms of out-ofhospital cardiac arrests : a report from a large-scale 
population-based cohort study. Resuscitation, 2013 ; $84: 558 \sim 563$

16) Jabbari R, Engstrøm T, Glinge $C$, Risgaard B, Jabbari J, Winkel BG, Terkelsen CJ, Tilsted HH, Jensen LO, Hougaard M, Chiuve SE, Pedersen F, Svendsen JH, HaunsøS, Albert CM, Tfelt-Hansen J : Incidence and risk factors of ventricular fibrillation before primary angioplasty in patients with first ST-elevation myocardial infarction : a nationwide study in Denmark. J Am Heart Assoc, 2015 ; 4 : e001399

17) Aso S, Imamura H, Sekiguchi $Y$, Iwashita $T$, Hirano R, Ikeda U, Okamoto K : Incidence and mortality of acute myocardial infarction. A population-based study including patients with out-of-hospital cardiac arrest. Int Heart J, $2011 ; 52: 197 \sim 202$

18) Arntz HR, Willich SN, Schreiber C, Brüggemann T, Stern R, Schultheiss HP : Diurnal, weekly and seasonal variation of sudden death. Population-based analysis of 24,061 consecutive cases. Eur Heart J, 2000 ; 21 : $315 \sim 320$

19) Tanigawa-Sugihara K, Iwami T, Nishiyama $C$, Kitamura T, Goto M, Ando M, Nishiuchi T, Hayashi Y, Kawamura $\mathrm{T}$ : Association between atmospheric conditions and occurrence of out-of-hospital cardiac arrest. 10-year population-based survey in Osaka. Circ J, $2013 ; 77: 2073 \sim 2078$

20) Niiyama $M$, Tanaka $F$, Nakajima $S$, Itoh $T$, Matsumoto T, Kawakami M, Naganuma Y, Omama S, Komatsu T, Onoda T, Sakata K, Ichikawa T, Nakamura M : Population-based incidence of sudden cardiac and unexpected death before and after the 2011 earthquake and tsunami in Iwate, northeast Japan. J Am Heart Assoc, 2014 ; 3 : e000798

21) Mitamura H : Public access defibrillation : advances from Japan. Nat Clin Pract Cardiovasc Med, 2008 ; 5 : $690 \sim 692$
22) 総務省消防庁: 平成 26 年版 救急・救助の現況

23) Kitamura T, Iwami T, Kawamura T, Nagao K, Tanaka H, Hiraide A ; Implementation Working Group for the All-Japan Utstein Registry of the Fire and Disaster Management Agency : Nationwide public-access defibrillation in Japan. N Engl J Med, 2010 ; 362 : $994 \sim 1004$

24）坂本哲也：日本における AEDの設置状況と今後勧めら れる設置場所. 呼と循, $2010 ; 58: 1087 \sim 1095$

25) Mitani Y, Ohta K, Ichida F, Nii M, Arakaki Y, Ushinohama H, Takahashi T, Ohashi H, Yodoya N, Fujii E, Ishikura K, Tateno S, Sato S, Suzuki T, Higaki T, Iwamoto M, Yoshinaga M, Nagashima M, Sumitomo $\mathrm{N}$ : Circumstances and outcomes of out-of-hospital cardiac arrest in elementary and middle school students in the era of public-access defibrillation. Circ J, $2014 ; 78: 701 \sim 707$

26) Mitani Y, Ohta K, Yodoya N, Otsuki S, Ohashi H, Sawada H, Nagashima M, Sumitomo N, Komada Y : Public access defibrillation improved the outcome after out-of-hospital cardiac arrest in school-age children : a nationwide, population-based, Utstein registry study in Japan. Europace, $2013 ; 15: 1259 \sim 1266$

27) Mitamura H, Iwami T, Mitani Y, Takada S, Takatsuki $\mathrm{S}$ : Aiming for zero deaths : prevention of sudden cardiac death in schools - Statement from the AED Committee of the Japanese Circulation Society. Circ J, $2015 ; 79$ : 1398 1401

28) Bardy GH, Lee KL, Mark DB, Poole JE, Toff WD, Tonkin AM, Smith W, Dorian P, Packer DL, White RD, Longstreth WT Jr, Anderson J, Johnson G, Bischoff E, Yallop JJ, McNulty S, Ray LD, Clapp-Channing NE, Rosenberg Y, Schron EB ; HAT Investigators : Home use of automated external defibrillators for sudden cardiac arrest. N Engl J Med, 2008 ; 358 : 1793 1804 